\title{
THE EVALUATION OF BANK PERFORMANCE USING A MULTICRITERIA DECISION MAKING MODEL: A CASE STUDY ON LITHUANIAN COMMERCIAL BANKS
}

\author{
Jelena Stankevičienè $\dot{e}^{1}$ Evelina Mencaitè ${ }^{2}$
}

Vilnius Gediminas Technical University, Sauletekio al. 11, LT-10223 Vilnius, Lithuania

E-mails: ${ }^{1}$ jelena.stankeviciene@vgtu.lt (corresponding author); ${ }^{2}$ e.mencaite@gmail.com

Received 18 December 2010; accepted 24 October 2011

\begin{abstract}
The paper presents an attempt to adopt a muticriteria decision making approach, particularly the Analytical Hierarchy Process (AHP) model, and to evaluate the performance of banks. The model is based on a system of various qualitative and quantitative criteria and their mutual relations. A system of indicators is created and described and each indicator is assigned a different degree of significance taking into account the needs and priorities of both internal and external evaluators. Model adaptation to Lithuanian market and an empirical test enabled to compare banks between each other, reveal their ranking and identify the banks taking leading positions in the market. The conducted research has concluded that the Analytical Hierarchy Process (AHP) model is appropriate for using it in the process valuating bank performance.
\end{abstract}

Keywords: bank performance, evaluation criteria, multicriteria decision model, Analytical Hierarchy Process (AHP).

Reference to this paper should be made as follows: Stankevičienė, J.; Mencaite, E. 2012. The evaluation of bank performance using a multicriteria decision making model: a case study on Lithuanian commercial banks, Technological and Economic Development of Economy 18(1): 189-205.

JEL Classification: C44, C69, G21, G32.

\section{Introduction}

The evaluation of banks and their performance attracts significant attention from public and financial regulators as banks are critical institutions in most economies. Their ability to attract financial resources and provide various credit operations and different financial services activate financial flows that influence the growth and economic development of a nation. Moreover, the banking sector is considered as a vital segment of modern economy, 
the existence economy of which cannot implement its role and carry out specific functions. There is no doubt that in order to ensure a healthy financial system together with efficient economy, banks must be evaluated and analyzed using the most accurate and modern evaluation techniques and, additionally, compared between each other in order to distinguish those leading and standing behind.

Recent financial turmoil has drawn even more discussions regarding the topic of banks and their performance evaluation as bank runs became more apparent and disturbing trends towards bank performance were observed. The need to evaluate banks in a more efficient way was identified and enhanced not only by supervising institutions, regulators and bank management bodies but also by clients, as their concern about the stability and sustainability of these financial institutions has grown significantly. This influenced to rethink the current performance evaluation techniques and models along with their applicability and improvement.

The novelty of this paper is reflected by creating a new model for evaluating banks and their performance. The model is based on a multicriteria approach, brings together financial and non-financial evaluation measures and consists of applying the multiciteria decision making technique such as Analytical Hierarchy Process (AHP). The adaptation of the AHP model helps with evaluating banks and their performance by combining different advantages of multicriteria decision making with a single balanced system. The model also can be considered as the universal one because it can be applied and used by both professional analysts and the clients of a bank as it requires information available in public sources.

The theory and practice have provided a number of valuation models but hardly any balanced methodology could be found. Also, an obvious point is that even the failure of one bank can have significant outcomes for the whole banking sector in the country and the performance of banks must be followed in a structured and efficient manner.

\section{Previous researches on the performance evaluation of banks}

This section of the paper will represent a review of previous researches made in the field evaluating bank performance. The analysis of different approaches and ideas will help with identifying the most valuable measures and methodologies and see the linkages to the evaluation model provided in this paper.

In an attempt to monitor and evaluate the performance of banks, most financial economists and analysts have been using financial ratios (Ayadi et al. 1998). The most popular and commonly used ones are return on equity (ROE) and return on assets (ROA). Badreldin (2009) agreed on insights provided by Lindblom and Von Koch (2002) and Wilcox (1984), who were asserting that return on equity as a financial measure could be discovered in the majority of research analyzing the performance of banks and concern analyst reports or company financial results. It is also important to highlight, that in the banking sector, ROA and ROE measures largely correlate with each other and both of them provide particularly the same indication of performance associated with the tendency and movement of financial performance (Karr 2005) (Table 1). 
Table 1. An overview of previous researches on the performance evaluation of banks

\begin{tabular}{|c|c|}
\hline Authors & Method \\
\hline $\begin{array}{l}\text { Wilcox (1984) } \\
\text { Karr (2005) } \\
\text { Badreldin (2009) }\end{array}$ & $\begin{array}{l}\text { Emphasized the importance of ROA and } \mathrm{ROE} \text { measures for evalu- } \\
\text { ating bank performance. These measures were considered as the } \\
\text { main performance indicators. }\end{array}$ \\
\hline $\begin{array}{l}\text { Sherman, Gold (1985) } \\
\text { Yeh (1996) }\end{array}$ & $\begin{array}{l}\text { Criticized the usage of benchmark ratios for the performance } \\
\text { evaluation of banks. }\end{array}$ \\
\hline $\begin{array}{l}\text { Banker, Morey (1986) } \\
\text { Weber (1996) }\end{array}$ & $\begin{array}{l}\text { For bank evaluation, the DEA approach- a mathematical program- } \\
\text { ming technique was used. }\end{array}$ \\
\hline $\begin{array}{l}\text { Avkiran (1997) } \\
\text { Lindblom, Von Koch (2002) } \\
\text { Chapman et al. (2007) }\end{array}$ & Provided the main shortcomings of ROE and ROA measures. \\
\hline Meyer, Markiewicz (1997) & $\begin{array}{l}\text { Have identified critical success factors of banking performance } \\
\text { and grouped them into eight main categories: 1) profitability, 2) ef- } \\
\text { ficiency and productivity, 3) human resource management, 4) risk } \\
\text { management, 5) sales effectiveness, 6) service quality, 7) capital } \\
\text { management, and 8) competitive positioning. }\end{array}$ \\
\hline $\begin{array}{l}\text { Ayadi et al. (1998) } \\
\text { Hays et al. (2009) }\end{array}$ & $\begin{array}{l}\text { Five main segments of bank operation are analyzed: capital adequa- } \\
\text { cy, asset quality, management quality, earnings ability and liquidity } \\
\text { (CAMEL). Sensitivity is added and CAMEL is model introduced. }\end{array}$ \\
\hline $\begin{array}{l}\text { Kalhoefer, Salem (2008) } \\
\text { Badreldin (2009) } \\
\text { Collier, McGowan (2010) }\end{array}$ & $\begin{array}{l}\text { Looked at the evaluation of banks through the usage of the Du Pont } \\
\text { System for Financial Analysis. The evaluation of performance was } \\
\text { separated into three elements: 1) net profit margin, 2) total asset } \\
\text { turnover and 3) the equity multiplier. }\end{array}$ \\
\hline Spathis et al. (2002) & $\begin{array}{l}\text { Observed strong linkages between bank size (non-financial mea- } \\
\text { sure) and performance. Multicriteria methods of M.H.DIS and } \\
\text { UTADIS were applied. }\end{array}$ \\
\hline $\begin{array}{l}\text { Manandhar, Tang (2002) } \\
\text { Chen, T. and Chen, C. (2008) }\end{array}$ & $\begin{array}{l}\text { Were analyzing the application of BSC to evaluate performance } \\
\text { not only by financial measures but also by incorporating the non- } \\
\text { financial approach. }\end{array}$ \\
\hline Chen, T., Chen, C. (2008) & Emphasized the role of non-financial measures to evaluate banks. \\
\hline Cicea, Hincu (2009) & $\begin{array}{l}\text { For bank performance evaluation, used the approach of investment } \\
\text { activities and introduced several methods: 1) financial indicators } \\
\text { (such as safety margin vis-à-vis investment risks, the rate of em- } \\
\text { ploying resources in investment, the rate of employing deposits in } \\
\text { investment and investment profitability), 2) quantitative models } \\
\text { (such as Sharp' model, Treanor's measure of performance, Jensen's } \\
\text { measure of performance). }\end{array}$ \\
\hline European Central Bank (2010) & $\begin{array}{l}\text { Suggests using a system of financial ratios combined of three catego- } \\
\text { ries: 1) traditional measures of performance, 2) economic measures } \\
\text { of performance and } 3 \text { ) market based measures of performance. } \\
\text { Rating agencies consider all types of prudential returns such as } \\
\text { capital, asset quality, liquidity that are integrated in measuring the } \\
\text { performance of a bank. }\end{array}$ \\
\hline
\end{tabular}


Although these measures are used widely, they are criticized and have significant shortcomings that are proposed by different financial analysts and scientists. The main limitations of ROE are as follows: 1) can induce inaccurate and incorrect results because of a different size of companies and in terms of credit risk (Lindblom, Von Koch 2002), 2) face the problems connected with the allocation of assets, equity and net income in case of branch level (Avkiran 1997), 3) the cost of equity is not taken into account in its calculation, thus it can be seen that bank performance is good when the value to its shareholders is diminishing. Moreover, when talking about ROA, as it was proposed by Chapman et al. (2007), this measure deals with some technical issues like: what assets should be included in the denominator, how to count income used in the numerator and the impact of different valuation rules such as replacement cost accounting.

Another block of literature concerning the measurement of bank performance concentrates on the sets of ratios or entire systems of measures. Most of these systems with minor adjustments and replacements are created on the basis of the Du Pont System for Financial Analysis (Badreldin 2009; Tamošaitienè 2011). One of these systems is Schierenbeck's Basic ROE Scheme. This model has three important advantages: the ability to conform an overall view of bank performance, the ease of gathering and obtaining information necessary for making calculations of its ratios and includes ROA in its analysis that helps with combining the advantages of both measures (Kalhoefer, Salem 2008).

The return on equity model analyzed by Collier and McGowan (2010) is also based on the Du Pont system, though in contrast to Schierenbeck's Basic ROE Scheme separates performance into three elements that determine return on equity: 1) net profit margin, 2) total asset turnover and 3) equity multiplier. This system allows evaluating the income statement and its components by using profit margin measure, meanwhile, the total asset turnover and equity multiplier helps with evaluating the left-hand side of the balance sheet composed of asset accounts and the right-hand side of the balance sheet that comprises liabilities and owner's equity.

European Central Bank (2010) suggests using the system of financial ratios. Traditional measures of performance comprise such ratios as ROA, ROE, cost-to-income ratio and net interest margin. Meanwhile, economic measures include EVA (economic value added) and RAROC (risk-adjusted return on capital). Finally, market-based measures of performance characterize the activity of a company valued by capital markets compared with the estimated accounting or economic value. The most commonly used metrics include total share return (TSR), price-earnings ratio (P/E), price-to-book value $(\mathrm{P} / \mathrm{B})$ and credit default swap (CDS).

If we have a look at the evaluation of bank performance from the point of rating agencies, they follow a more holistic approach. As rating agencies make an overall assessment of banks and assigning grades, they consider all types of prudential returns such as capital, asset quality and liquidity that are integrated in measuring the performance of a bank. Besides, they take a more dynamic approach and more attention is paid to changes in revenue composition and cost elements. Rating agencies also try to add market-based indicators while analyzing the performance of banks (European Central Bank 2010).

For the evaluation of bank performance, Cicea and Hincu (2009) used an approach to investment activities and introduced several methods: 1) financial indicators, 2) quantitative 
models (Sharp model, Treynor's measure of performance, Jensen's measure of performance). Researchers also analyzed the possibility of applying these quantitative models and made the conclusion that Sharp model was considered the most appropriate in terms of data availability in commercial banks.

However, the usage of financial ratios and their systems is criticized by other scientists. Yeh (1996) notes that dependence on benchmark ratios, i.e. reliance on comparable norms and standards is the most significant shortage of financial ratios approach that does not allow to composite an overall score on the entire bank soundness. Moreover, Sherman and Gold (1985) point out those financial ratios mainly reflect short-term rather than long-term measures of performance that is more relevant. According to them, financial ratios combine many aspects of performance, including operations, marketing and financing. Thus, such an approach is not appropriate.

As a result, CAMEL and DEA approaches were introduced in literature on evaluating bank performance. The acronym CAMEL is derived from the five main segments of bank operation: Capital adequacy, Asset quality, Management quality, Earnings ability and Liquidity (CAMEL). Moreover, Hays et al. (2009) presented the enhancement of the CAMEL model by federal banking regulators in order to assess the overall performance of commercial banks. Regulators created an additional measure, sensitivity, to evaluate market risk associated with changing interest rates and other factors.

DEA (Data Envelopment Analysis) was developed by Charnes in 1978 and considered mathematical programming technique calculating the relative efficiency of objects on multiple criteria (Banker, Morey 1986). Mathematically, as Step 1, DEA identifies an "efficient frontier" comprised of analyzing the outputs and inputs of a certain set of objects that will be evaluated and called decision making units (DMUs) (Weber 1996). According to Ayadi et al. (1998), the DEA approach should be considered as a relative measure of efficiency as it identifies the 'best practice' firm in a group according to the observed outputs and inputs. Then, each firm in the group is evaluated relatively to the 'best' firm.

Chen, T. and Chen, C. (2008) began a discussion that, traditionally, many performance measures and their schemes have been based on financial aspects, whereas non-financial aspects were ignored, although their role in performance evaluation is important. They also propose that the evaluation of bank performance usually employs financial indices, thus providing a simple description about the financial performance of the bank in comparison to the previous periods and focusing only on financial aspects. However, this is not enough to keep in line with a changing environment in business.

In 1996, Kaplan and Norton introduced the concept of a Balanced Scorecard (BSC), which was proposed as background for a strategic management system (Kaplan, Norton 2004). The main feature of this approach is that financial and non-financial aspects were included and allowed incorporating business strategies into management systems. Manandhar and Tang (2002) concluded that BSC was not only a system for measuring performance but also a system of strategy analysis. However, one aspect has been considered as a disadvantage of the BSC system; therefore, it is difficult to make comparisons within and across companies on such a basis (Chen, T., Chen, C. 2008).

Abdelgawad, Fayek (2010) developed an approach provided by Meyer and Markiewicz who identified critical success factors in banking performance and grouped them into eight 
main categories: 1) profitability, 2) efficiency and productivity, 3) human resource management, 4) risk management, 5) sales effectiveness, 6) service quality, 7) capital management and 8) competitive positioning. Financial and non-financial measures are combined together into the balanced system, which takes into account different fields of banking activity. It can be proposed that such approach helps with evaluating bank performance in a more comprehensive manner.

Finally, the study made by Spathis et al. (2002) presented strong linkages between bank size (non-financial measure) and performance efficiency were identified. In order to identify the differences of profitability and operation related with the size of banks, the multicriteria methods of M. H. DIS and UTADIS were applied. Seven financial ratios were selected for examination: return on equity, return on assets, net interest margin, the ratio of loans to deposits, the ratio of current assets to total loans, total assets to the total equity ratio and the ratio of total equity to total assets. The results indicated that large banks were more efficient than the small ones that can be characterized by high capital yield (ROE), high interest rate yield (MARG), high financial leverage (TA/TE) and high capital adequacy (TE/TA). Meanwhile, large banks can be considered as having high asset yield (ROA) and low capital and interest rate yield.

To sum up, it can be proposed that observations and literature analysis according to the measurement of bank performance clearly show that different techniques and methods can be applied in this field. The main purpose of creating the evaluation process is to choose those ratios and methods, including financial and non-financial measures that would reflect the most accurate view of banking activities and would help with solving a specific problem of evaluation.

\section{Development of the model}

This section of the paper is designated for highlighting the main aspects of developing the AHP model applied for evaluating the performance of banks. It will cover such topics as an overview of applying the AHP model, the structure of the model and, finally, a detailed sequence and steps necessary to apply this technique.

The AHP model was chosen based on several reasons. First, it allows considering financial and non-financial measures in the evaluation process, which is very important because the business of banking is very complex, and therefore it is not enough to take into account only financial measures. It helps with revealing bank ranking and recognizing better performing banks and those that need more attention either from supervisory institutions or management in order to improve the current performance. This model also includes external judgment that could help with building a more specific evaluation framework.

The AHP model can be considered as a new approach that got full attention in the recent years and found its applicability in different fields. Zavadskas and Kaklauskas developed a method of a multiple criteria complex proportional assessment of projects for determining the priority and utility degree of alternatives. Lithuanian and foreign scientists applied the original or expanded method for solving different engineering and management multiattribute problems in the period of 1996-2011 (Zavadskas et al. 2008, 2009a, 2009b; Podvezko et al. 2010; Tupenaite et al. 2010; Sivilevicius 2011a, 2011b; Lashgari et al. 2011). Haq and 
Kannan (2006) used this approach for selecting a vendor, Kaya and Kahraman (2011) - for developing e-banking website quality assessment, Hsu (2006) - for developing a new model to select public relation firms in high-tech industry, Wu et al. (2010) - for evaluating business performance of wealth management banks. These examples show that AHP can be considered as a beneficial approach and appreciated by many researchers.

The analysis of researches and case studies provided above indicates that AHP consists of four main fragments depicted in Figure 1.

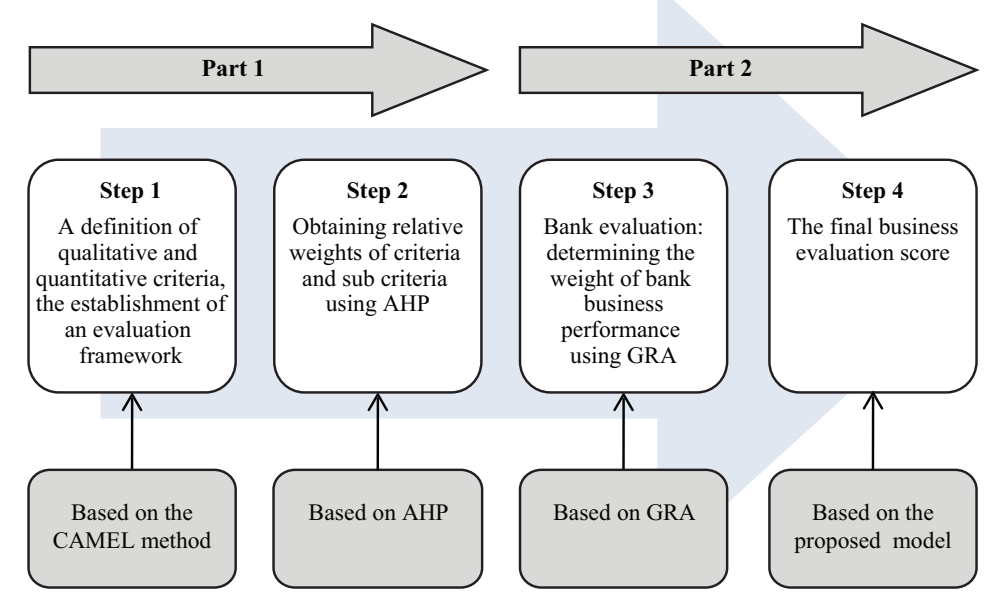

Fig. 1. The main steps in the application of the proposed model

It can be noticed that the application of the model begins from a definition of qualitative and quantitative criteria. Further, the AHP technique is applied to find out relative weights between the chosen criteria. The outcome of the applied model would be ranking banks, which will allow not only evaluating banks but also identifying better bank performance considering the banks that could be considered as showing a lower performance level (Gnanasekaran et al. 2008).

As proposed by Hsu (2006), the model can be divided into two major parts: in the first one, the AHP approach is applied and in the second - GRA application is involved. These two major parts comprises smaller and more detailed elements and procedures provided below. The interpretation of these elements and procedures is based on research made by Hsu (2006), Wu et al. (2010), Farhan, Fwa (2010).

Part 1 involves the application of AHP for defining relative criteria weightings. This part comprises six following steps (based on Hsu 2006; Wu et al. 2010):

1) the definition evaluating criteria and sub-criteria and both qualitative and quantitative measures;

2) the establishment of a hierarchical structure breaking the problem of evaluating bank performance into the hierarchy of interconnected decision elements containing a) the ultimate goal, b) criteria and c) sub-criteria; 
3) the establishment of a pair-wise comparison matrix where a pair-wise comparison of decision elements is made by an expert and relative scores are assigned;

4) to calculate the eigenvector of each matrix of the pair-wise comparison;

5) this step consists of testing the consistency of each comparison matrix;

6) to estimate the relative weights of the elements at each level;

7) the definition of criteria and data treatment;

8) the normalization of individual values of the criteria before calculating relational grades, in case of variances between individual criteria units;

9) to calculate the difference series;

10) to compute relational coefficients;

11) to compute a relational grade;

12) to reveal the ranking of the chosen banks to determine the best performing banks and those falling behind.

To sum up this section, the AHP methods provide a comprehensive tool for conducting analysis in different fields, including business performance evaluation, the selection of suppliers, projector environment evaluation, etc. The main advantage of researches using this model is that both qualitative and quantitative criteria can be taken into consideration. The AHP method could be easily applied for finding a solution to the problem. Moreover, Gnanasekaran et al. (2008), state that another major advantage of this integrated model is flexibility as the employment of this model makes it easy to include any new subject (supplier, bank, project, etc.) in the evaluation process.

\section{The application of the proposed model: a case study on Lithuanian commercial banks}

This section describes the application of the AHP model and investigates the performance of Lithuanian commercial banks. The application process of the AHP model begins from the establishment of an evaluation framework comprised of different evaluation criteria, including quantitative and qualitative measures.

The evaluation framework of this research is based particularly on observations made by several scientists who were dealing with evaluating the business and performance of banks (Wu et al. 2010) and on adding additional criteria. Overall, the evaluation model consists of 22 different criteria (Fig. 2).

The problem of the evaluation of bank performance was decomposed or split into a hierarchy of interconnected decision components containing: a) the ultimate goal, b) criteria and c) sub-criteria, i.e. the problem of identifying the best performing commercial banks and those that fall behind according to the chosen evaluation framework can be solved by evaluating customer perspective criteria, financial perspective criteria and qualitative evaluation criteria.

In Step 3, a pair-wise comparison procedure should be applied. The procedure is established with the help of an expert review of decision elements (both criteria and sub-criteria) and the assignment of relative scores, i.e. a pair-wise comparison shows the importance 


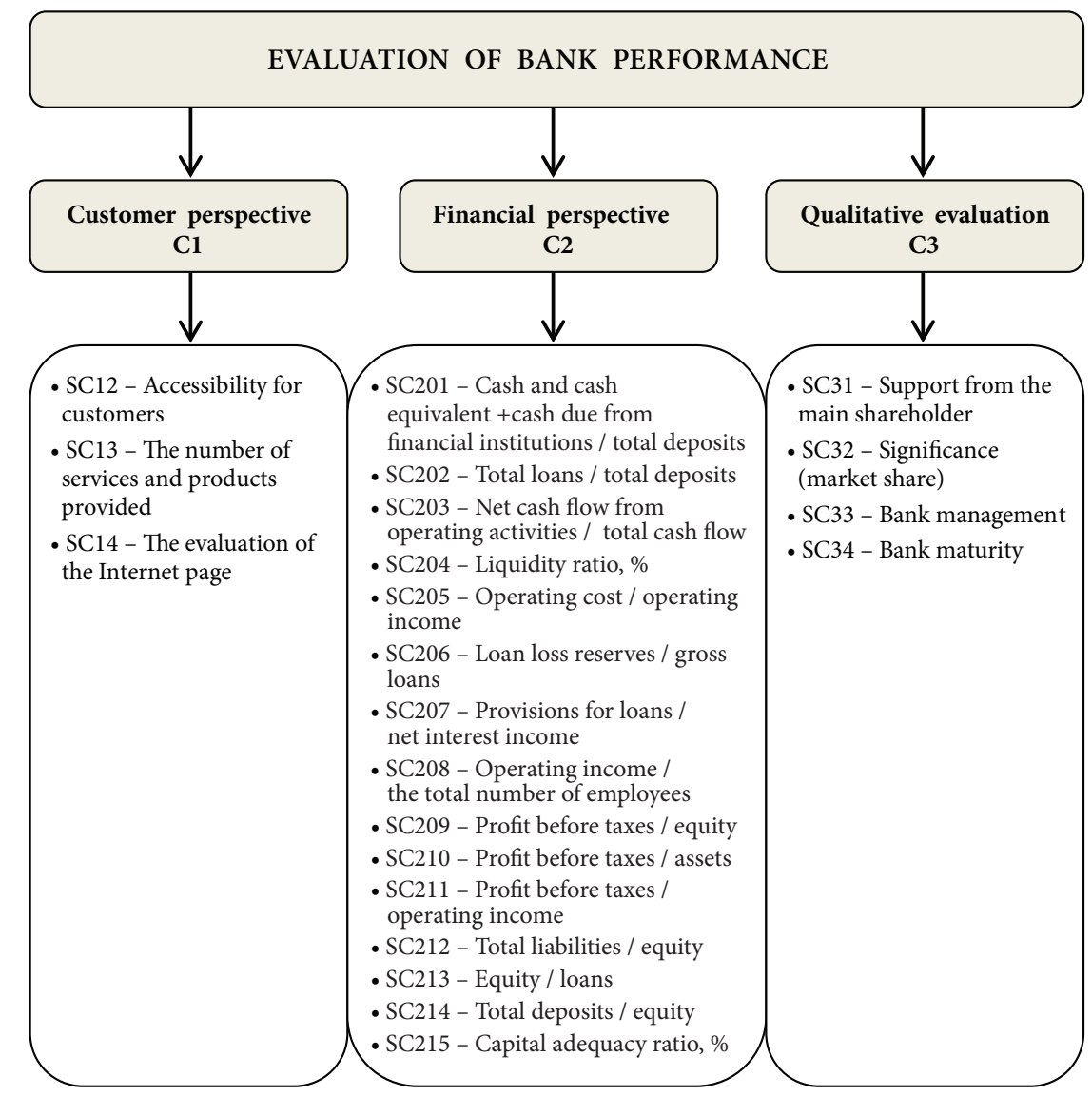

Fig. 2. A hierarchical structure of the evaluation model for Lithuanian commercial banks

of one element over the element it is compared with. The pair-wise comparison matrix is established using Formula (1):

$$
A=\left\{\begin{array}{cccc}
1 & a_{12} & \ldots & a_{1 n} \\
\frac{1}{a_{12}} & 1 & \ldots & a_{2 n} \\
\vdots & \vdots & \ldots & \vdots \\
\frac{1}{a_{1 n}} & \frac{1}{a_{2 n}} & \ldots & 1
\end{array}\right\} .
$$

The structure of the matrix is comprised of the compared elements and relative weights. The diagonal cells of the matrix always have the meaning of 1 , as the same elements have no importance or difference between each other.

The comparison matrix of the main criteria ( $\mathrm{C} 1$ - customer perspective; $\mathrm{C} 2$ - financial perspective; C3 - qualitative evaluation) is provided below in Table 2. 
Table 2. The pair-wise comparison matrix of the main criteria

\begin{tabular}{lccc}
\hline & C1 & C2 & C3 \\
\hline C1 & 1 & $1 / 7$ & $1 / 3$ \\
\hline C2 & 7 & 1 & 4 \\
\hline C3 & 3 & $1 / 4$ & 1 \\
\hline Total & 11 & 1.393 & 5.333 \\
\hline
\end{tabular}

The pair-wise comparison matrix of the main criteria showed that financial perspective was dominant over customer perspective and qualitative evaluation. On the other hand, customer perspective is characterized as less important than qualitative evaluation.

Moreover, the comparison matrixes of importance were established for sub-criteria that are falling under the main categories.

Step 4 can be considered as the step of calculating the eigenvector of each pair-wise comparison matrix.

First, for eigenvector calculation, Sivilevičius and Maskeliūnaite (2010), Podvezko et al. (2010) suggest adding the columns of each pair-wise comparison matrix. Then, the values of the matrix should be normalized by dividing each element in the column from the total score of column values. When the matrix with normalized values is established, the mean of every row is provided with an eigenvector. The calculations of the first eigenvector were implemented taking the main criteria. The table of the eigenvectors of the main criteria indicates that financial perspective is the most important criteria (0.7014) comparing with the values of the eigenvectors of customer perspective (0.0853) and qualitative evaluation (0.2132) criteria (Table 3).

The difference between the eigenvector of financial and customer perspective criteria is very obvious. Moreover, the eigenvectors of each element at sub-criteria level were calculated.

Table 3. The values of the eigenvectors of the main criteria

\begin{tabular}{ccccc}
\hline & C1 & C2 & C3 & Eigenvector \\
\hline C1 & 0.091 & 0.103 & 0.063 & 0.0853 \\
\hline C2 & 0.636 & 0.718 & 0.750 & 0.7014 \\
\hline C3 & 0.273 & 0.179 & 0.188 & 0.2132 \\
\hline
\end{tabular}

Step 5 of the AHP model provides an ability to test the consistency of each comparison matrix using formulas (2) and (3):

$$
\begin{gathered}
C I=\frac{\lambda_{\max }-n}{n-1} ; \\
C R=\frac{C I}{R I} .
\end{gathered}
$$

Although in some researches this step is not included, it can be considered to be of key importance a sit helps with detecting inconsistencies in the evaluations and rankings of the preferences estimated by experts or evaluators.

The summary of the consistency test and calculations is provided in Table 4 . 
Table 4. A summary of the consistency test

\begin{tabular}{lcccc}
\hline & Main criteria & C1 & C2 & C3 \\
\hline $\mathrm{RI}$ & 0.580 & 0.580 & 1.590 & 0.900 \\
\hline$\lambda_{\max }$ & 3.052 & 3.039 & 16.290 & 4.130 \\
\hline $\mathrm{CI}$ & 0.026 & 0.019 & 0.092 & 0.043 \\
\hline $\mathrm{CR}$ & 0.045 & 0.034 & 0.057 & 0.048 \\
\hline $\mathrm{n}$ & 3.000 & 3.000 & 15.000 & 4.000 \\
\hline
\end{tabular}

If the matrix consists of less than 5 criteria, the requirement for consistency ratio $(\mathrm{CR})$ is $\mathrm{CR}<0.05$. The table above indicates that the matrixes of the main criteria, $\mathrm{C} 1$ and $\mathrm{C} 3 \mathrm{sub}-$ criteria are consistent because their CR scores are $0.046,0.034$ and 0.048 respectively. On the other hand, if the matrix consists of more than 5 criteria, CR should already be less than 0.1 . As the C2 sub-criteria matrix consists even of 15 measures and its CR equals 0.058 , it can be also considered as consistent.

Thus, it could be concluded that preferences indicated in the evaluation are correct and further steps of the proposed model can be applied.

The last step in the first part of model application is Step 6 estimating the relative or global weights of the elements at each level. The weights of the criteria within a certain group have already been estimated and this step is dedicated exclusively for calculating the overall weight of the criteria in the entire evaluation system.

In order to estimate the overall weights, the eigenvector of the criterion is multiplied by the relative weight of the group it belongs to. The obtained results showed that there were four top ratios recognized based on an expert review. These include significance (0.105798), liquidity ratio (0.105235), capital adequacy ratio (0.099951) and proportion between net cash flow from operating activities and total cash flow (0.092347).

Step 7 requires estimates, the definition of the criteria and data treatment. As there are even 22 criteria included in the evaluation process, the table below has been established to enable data analysis quicker and easier (Table 5).

Next, Step 9 requires proceeding with model application considering the normalization of individual criteria values prior to the calculation of relational grades, in case of the variances between individual criteria units. Data normalization is implemented in order to convert the values of criteria into series from 0 to 1 and continue calculations. This procedure helps with a comparison of how banks are performing in terms of a single criterion.

Step 10 can be considered as the one calculating difference series determined deducting the actual values of normalized individual criteria from referential series.

The next step calculates grey relational coefficients in order to express the relationship and connection between the best (reference) and the actual normalized values. These coefficients must be estimated prior the relational grade is obtained and fluctuate within the range from 0 to 1 . According to Jangraa et al. (2011), the relational grade can be interpreted as a weighting-sum of relational coefficients. The relational grades of Lithuanian commercial banks are shown in Table 6 indicating the grades assigned for each commercial bank in terms of a single criterion. The grades marked in bold are considered as 'the best' ones while the 
scores marked in grey are the lowest within the group. The provided information suggests that the majority of banks have gathered from 4 to 6 'best' scores and that the lowest scores are concentrated in predominantly three commercial banks.

Table 5. The rates of data series

\begin{tabular}{cccccccccc}
\hline & X1 & X2 & X3 & X4 & X5 & X6 & X7 & X8 & X9 \\
\hline SC12 & 1.000 & 1.501 & 1.390 & 0.663 & 0.575 & 0.008 & 0.213 & 0.696 & 0.147 \\
\hline SC13 & 1.000 & 0.667 & 0.333 & 0.333 & 0.667 & 0.333 & 0.667 & 1.000 & 0.667 \\
\hline SC14 & 0.909 & 0.818 & 1.000 & 1.000 & 0.909 & 0.727 & 0.818 & 1.000 & 1.000 \\
\hline SC201 & 0.593 & 0.815 & 1.037 & 0.593 & 0.519 & 0.963 & 0.444 & 1.000 & 0.407 \\
\hline SC202 & 0.785 & 0.308 & 0.439 & 1.000 & 0.537 & 0.131 & 0.463 & 0.271 & 0.346 \\
\hline SC203 & 0.773 & 2.021 & 0.290 & 1.000 & 0.008 & 0.201 & 0.021 & 1.704 & 0.976 \\
\hline SC204 & 1.001 & 1.328 & 1.217 & 1.000 & 0.915 & 1.957 & 1.283 & 1.376 & 1.513 \\
\hline SC205 & 0.982 & 1.088 & 1.316 & 1.000 & 2.281 & 1.754 & 1.158 & 2.246 & 0.930 \\
\hline SC206 & 0.006 & 0.365 & 0.029 & 1.000 & 0.000 & 0.000 & 0.088 & 1.465 & 2.235 \\
\hline SC207 & 1.000 & 0.338 & 0.167 & 0.581 & 0.451 & 0.013 & 0.431 & 8.801 & 0.550 \\
\hline SC208 & 1.000 & 0.772 & 0.830 & 1.030 & 0.355 & 0.567 & 0.364 & 0.518 & 0.372 \\
\hline SC209 & 1.000 & 0.500 & 3.500 & 7.000 & 14.500 & 0.500 & 5.500 & 5.500 & 18.500 \\
\hline SC210 & 1.000 & 0.615 & 5.154 & 8.385 & 34.538 & 0.923 & 9.538 & 6.769 & 32.385 \\
\hline SC211 & 1.000 & 0.600 & 4.400 & 7.600 & 28.400 & 0.200 & 13.400 & 10.800 & 16.200 \\
\hline SC212 & 0.902 & 0.974 & 0.718 & 1.000 & 0.455 & 0.642 & 0.669 & 0.920 & 0.650 \\
\hline SC213 & 1.222 & 1.556 & 1.667 & 1.000 & 2.222 & 5.556 & 1.667 & 2.000 & 2.111 \\
\hline SC214 & 1.087 & 2.131 & 1.403 & 1.000 & 0.849 & 1.393 & 1.296 & 1.940 & 1.399 \\
\hline SC215 & 1.259 & 0.813 & 1.585 & 1.000 & 1.420 & 1.064 & 1.077 & 0.964 & 1.244 \\
\hline SC31 & 1.000 & 0.667 & 1.000 & 1.000 & 1.000 & 0.667 & 0.333 & 0.333 & 0.333 \\
\hline SC32 & 1.000 & 0.667 & 1.000 & 1.000 & 0.333 & 0.333 & 0.333 & 0.667 & 0.333 \\
\hline SC33 & 1.000 & 1.000 & 0.667 & 1.000 & 0.333 & 0.333 & 1.000 & 0.667 & 0.667 \\
\hline SC34 & 0.333 & 0.667 & 0.667 & 0.667 & 0.333 & 0.333 & 0.667 & 1.000 & 0.667 \\
\hline & & & & & & & & & \\
\hline
\end{tabular}

Table 6. Relational grades of Lithuanian commercial banks

\begin{tabular}{cccccccccc}
\hline & X1 & X2 & X3 & X4 & X5 & X6 & X7 & X8 & X9 \\
\hline SC12 & 0.029 & 0.049 & 0.043 & 0.023 & 0.022 & 0.016 & 0.018 & 0.024 & 0.017 \\
\hline SC13 & 0.029 & 0.015 & 0.015 & 0.015 & 0.015 & 0.010 & 0.015 & 0.029 & 0.015 \\
\hline SC14 & 0.004 & 0.003 & 0.007 & 0.007 & 0.004 & 0.002 & 0.003 & 0.007 & 0.007 \\
\hline SC201 & 0.026 & 0.038 & 0.065 & 0.027 & 0.024 & 0.053 & 0.023 & 0.061 & 0.022 \\
\hline SC202 & 0.036 & 0.021 & 0.024 & 0.055 & 0.026 & 0.018 & 0.024 & 0.020 & 0.022 \\
\hline SC203 & 0.031 & 0.092 & 0.041 & 0.053 & 0.038 & 0.040 & 0.038 & 0.075 & 0.053 \\
\hline SC204 & 0.037 & 0.048 & 0.043 & 0.037 & 0.035 & 0.105 & 0.046 & 0.050 & 0.057 \\
\hline SC205 & 0.019 & 0.016 & 0.013 & 0.018 & 0.007 & 0.009 & 0.015 & 0.007 & 0.020 \\
\hline SC206 & 0.020 & 0.016 & 0.020 & 0.011 & 0.021 & 0.021 & 0.019 & 0.009 & 0.007 \\
\hline SC207 & 0.006 & 0.006 & 0.006 & 0.006 & 0.006 & 0.006 & 0.006 & 0.018 & 0.006 \\
\hline
\end{tabular}


End of Table 6

\begin{tabular}{cccccccccc}
\hline & X1 & X2 & X3 & X4 & X5 & X6 & X7 & X8 & X9 \\
\hline SC208 & 0.011 & 0.007 & 0.008 & 0.012 & 0.004 & 0.005 & 0.004 & 0.005 & 0.004 \\
\hline SC209 & 0.020 & 0.022 & 0.016 & 0.012 & 0.009 & 0.020 & 0.014 & 0.014 & 0.007 \\
\hline SC210 & 0.021 & 0.023 & 0.018 & 0.016 & 0.008 & 0.022 & 0.015 & 0.016 & 0.008 \\
\hline SC211 & 0.016 & 0.018 & 0.013 & 0.011 & 0.006 & 0.017 & 0.009 & 0.010 & 0.008 \\
\hline SC212 & 0.021 & 0.019 & 0.028 & 0.018 & 0.055 & 0.033 & 0.031 & 0.020 & 0.032 \\
\hline SC213 & 0.014 & 0.015 & 0.015 & 0.014 & 0.017 & 0.042 & 0.016 & 0.016 & 0.017 \\
\hline SC214 & 0.038 & 0.017 & 0.028 & 0.042 & 0.052 & 0.028 & 0.031 & 0.019 & 0.028 \\
\hline SC215 & 0.054 & 0.033 & 0.100 & 0.040 & 0.070 & 0.043 & 0.043 & 0.038 & 0.053 \\
\hline SC31 & 0.027 & 0.013 & 0.027 & 0.027 & 0.027 & 0.013 & 0.009 & 0.009 & 0.009 \\
\hline SC32 & 0.106 & 0.053 & 0.106 & 0.106 & 0.035 & 0.035 & 0.035 & 0.053 & 0.035 \\
\hline SC33 & 0.061 & 0.061 & 0.031 & 0.061 & 0.020 & 0.020 & 0.061 & 0.031 & 0.031 \\
\hline SC34 & 0.007 & 0.010 & 0.010 & 0.010 & 0.007 & 0.007 & 0.010 & 0.020 & 0.010 \\
\hline
\end{tabular}

According to the theory, the highest relational grade shows the best alternative. The final score is calculated by simply adding all relational grades for a certain bank. As all calculations have already proceeded, the final ranking of Lithuanian commercial banks can be revealed.

The results provided in Table 7 propose that the best performing bank is bank X3 having score 0.676 . The second and third places are assigned to banks X1 and X4 with scores 0.635 and 0.621 respectively. What is more, no significant gap between the above evaluated commercial banks can be noticed. The lowest performance results were identified in banks X7 and $\mathrm{X} 9$ that got quite similar scores making 0.484 and 0.468 .

Table 7. Ranking Lithuanian commercial banks in terms of performance

\begin{tabular}{ccc}
\hline & Relational grade & Ranking \\
\hline Bank X1 & 0.635 & 2 \\
\hline Bank X2 & 0.597 & 4 \\
\hline Bank X3 & 0.676 & 1 \\
\hline Bank X4 & 0.621 & 3 \\
\hline Bank X5 & 0.508 & 7 \\
\hline Bank X6 & 0.566 & 5 \\
\hline Bank X7 & 0.484 & 8 \\
\hline Bank X8 & 0.552 & 6 \\
\hline Bank X9 & 0.468 & 9 \\
\hline
\end{tabular}

The conducted investigation has revealed that the difference in performance can be influenced by the size of a bank. The best performing banks belonging to small or medium bank categories are those X6 and X9.

In conclusion of this section of the paper, the AHP model can be successfully applied for Lithuanian banking market. Depending on the priorities of evaluators, different weights for criteria can be assigned, however, as the final result, ranking banks can be established and leading banks can be distinguished from those falling behind. 


\section{Conclusions}

Banks can be considered as extraordinary business entities that perform particularly specific functions such as the attraction of financial resources, the provision of various credit operations and different financial services and the activation of financial flows that have a significant impact on the growth and development of a nation. These financial institutions manage a portentous proportion of assets in the entire financial system and their performance together with an overall condition have a major influence on the stability and soundness of national economy.

Moreover, banking as a branch of industry has gone through a path of significant changes during last decades. Business models and processes have become more multifaceted and the number of services and areas of activity has increased several times. All these factors have lead to the situation indicating that the measurement of bank performance has became more sophisticated and as a result the need for a methodology fully reflecting different aspects of performance and satisfying different interests of clients, investors, supervising authorities and management of the bank have come to the front.

The first attempts to monitor and evaluate the performance of banks were mainly based on the analysis of various distinct financial indicators (return on assets, return on equity, capital adequacy, profitability, etc.) that later went through the process of grouping and were combined into entire financial systems of evaluation. Although financial ratios together with mathematical programming techniques were widely applied, a lack of non-financial evaluation was identified. There still was a necessity to create a solid and flexible evaluation technique or model.

The proposed model was introduced in order to eliminate the shortcomings of the previous methodologies and include considerable non-financial aspects to the evaluation framework. This model allows splitting the problem of evaluating the performance of banks into four major stages such as the definition of qualitative and quantitative criteria, the establishment of the evaluation framework, the acquisition of the relative weights of criteria and sub criteria using AHP, the determination of the weight business performance in banks and the final business evaluation score.

Following the analysis of literature on the performance of banks, three main pillars of financial and non-financial evaluation were identified and the application process of AHP was conducted. The first pillar of measures was evaluating the performance of banks from customer's perspective and consisted of such indicators as customer increasing rate, accessibility for a customer, the number of provided services and products, the quality of the Internet page. The second pillar covered financial ratios. Finally, the third pillar of measures, including support, significance, management and quality maturity of a bank was used for qualitative evaluation. Overall, the performance of banks was investigated using 22 criteria.

It should be noted, that the performance of banks can be influenced by their size. The interaction between these two aspects was identified in the carried out research. Smaller banks were falling behind the banks that were managing solid assets and controlling a significant part of the market. Banks X6 and X8 were performing best with the final scores of 0.566 and 0.552 respectively in the category of small or medium banks. 
The scope of applying the model proposed in this paper can be very wide as it can be employed by customers, investors, supervising authorities, the management of the bank and other shareholders. For the evaluation of commercial banks, the AHP model used publicly available information and does not require particularly extraordinary knowledge that is a great advantage for ordinary clients of the bank.

When looking to the prospects of the model, new criteria could be added and proportion between quantitative and qualitative measures modified in order to satisfy the needs of different evaluators by bringing out the most important aspects of performance. Finally, this model can be characterized as universal as it can be applied not only for Lithuanian market, but also in foreign countries.

\section{References}

Abdelgawad, M.; Fayek, R. 2010. Risk management in the construction, industry using combined fuzzy FMEA and fuzzy AHP, Journal of Construction Engineering and Management 136(9): 1028-1036. http://dx.doi.org/10.1061/(ASCE)CO.1943-7862.0000210

Avkiran, N. K. 1997. Models of retail performance for bank branches: predicting the level of key business drivers, International Journal of Bank Marketing 15(6): 224-237. http://dx.doi.org/10.1108/02652329710184451

Ayadi, O. F.; Adebayo, A. O.; Omolehinwa, E. 1998. Bank performance measurement in a developing economy: an application of data envelopment analysis, Managerial Finance 24(7): 5-16. http://dx.doi.org/10.1108/03074359810765589

Badreldin, A. M. 2009. Measuring the Performance of Islamic Banks by Adapting Conventional Ratios, German University in Cairo Working Paper No. 16 [online], [cited 10 February 2011]. Available from Internet: http://ssrn.com/abstract=1492192

Banker, R. D.; Morey, R. C. 1986. Efficiency analysis for exogenously fixed inputs and outputs, Operations Research 34(4): 513-521. http://dx.doi.org/10.1287/opre.34.4.513

Chapman, C. S.; Hopwood, A. G.; Shields, M. D. 2007. Handbook of Management Accounting Research, Vol. 1. Elsevier, ISBN-10: 0-08-044564-0 [online], [cited 15 February 2011]. Available from Internet: http://books.google.lt/books?id=zoZT1T9N5PcC\&dq=ISBN-10:+0-08-044564-0\&source=gbs_ navlinks_s

Chen, T.; Chen, C. 2008. Firm operation performance analysis using data envelopment analysis and balanced scorecard: a case study of credit cooperative bank, International Journal of Productivity and Performance Management 57(7): 523-539. http://dx.doi.org/10.1108/17410400810904010

Cicea, C.; Hincu, D. 2009. Performance evaluation methods in commercial banks and associated risks for managing assets and liabilities, Communications of the IBIMA 7: 97-101.

Collier, H. W.; McGowan, C. B. 2010. Evaluating the impact of a rapidly changing economic environment on bank financial performance using the Du Pont system of financial analysis, Asia Pacific Journal of Finance and Banking Research 4(4): 25-35.

European Central Bank 2010. Beyond ROE - How to Measure Bank Performance [online], [cited 21 February 2011]. Available from Internet: http://www.ecb.eu/pub/pdf/other/beyondroehowtomeasurebankperformance 201009en.pdf

Farhan, J.; Fwa, T. F. 2009. Pavement maintenance prioritization using analytic hierarchy process, Transportation Research Record 2093: 12-24. http://dx.doi.org/10.3141/2093-02

Haq, A. N.; Kannan, G. 2006. An integrated approach for selecting a vendor using grey relational analysis, International Journal of Information Technology \& Decision Making 5(2): 277-295.

http://dx.doi.org/10.1142/S0219622006001952 
Hays, F. H.; De Lurgio, S. A.; Gilbert, A. H. 2009. Efficiency ratios and community bank performance, Journal of Finance and Accountancy 1: 1-15.

Hsu, P. F. 2006. Developing a new model for selecting public relations firms in the high-tech industry, Journal of Modeling in Management 1(2): 156-172. http://dx.doi.org/10.1108/17465660610703486

Jangraa, K.; Grovera, S.; Aggarwalb, A. 2011. Simultaneous optimization of material removal rate and surface roughness for WEDM of WCCO composite using grey relational analysis along with Taguchi method, International Journal of Industrial Engineering Computations 2: 479-490. http://dx.doi.org/10.5267/j.ijiec.2011.04.005

Kalhoefer, C.; Salem, R. 2008. Profitability Analysis in the Egyptian Banking Sector, German University in Cairo Faculty of Management Technology Working Paper No. 7 [online], [cited 21 February 2011]. Available from Internet: http://mgt.guc.edu.eg/wpapers/007kalhoefer_salem2008.pdf

Kaplan, R. S.; Norton, D. P. 2004. Measuring the strategic readiness of intangible assets, Harvard Business Review 82(2): 52-63.

Karr, J. 2005. Performance measurement in banking: beyond ROE, Journal of Performance Measurement 18(2): 56-70.

Kaya, T.; Kahraman, C. 2011. A fuzzy approach to e-banking website quality assessment based on an integrated AHP-ELECTRE method, Technological and Economic Development of Economy 17(2): 313-334. http://dx.doi.org/10.3846/20294913.2011.583727

Lashgari, A.; Fouladgar, M. M.; Yazdani-Chamzini, A.; Skibniewski, M. J. 2011. Using an integrated model for shaft sinking method selection, Journal of Civil Engineering and Management 17(4): 569-580. http://dx.doi.org/10.3846/13923730.2011.628687

Lindblom, T.; Von Koch, C. 2002. Cross-border bank mergers and acquisitions in the EU, The Service Industries Journal 22(4): 41-72. http://dx.doi.org/10.1080/714005097

Manandhar, R.; Tang, C. S. 2002. The evaluation of bank branch performance using data envelopment analysis, The Journal of High Technology Management Research 13(1): 1-18. http://dx.doi.org/10.1016/S1047-8310(01)00045-1

Meyer, D. W.; Markiewicz, M. K. 1997. Developing a balanced scorecard at Wachovia Corporation, Bank Accounting and Finance 11(1): 13-19.

Podvezko, V.; Mitkus, S.; Trinkuniene, E. 2010. Complex evaluation of contracts for construction, Journal of Civil Engineering and Management 16(2): 287-297. http://dx.doi.org/10.3846/jcem.2010.33

Sherman, H. D.; Gold, F. 1985. Bank branch operating efficiency: evaluation with data envelopment analysis, Journal of Banking and Finance 9(2): 297-315. http://dx.doi.org/10.1016/0378-4266(85)90025-1

Sivilevicius, H. 2011a. Application of expert evaluation method to determine the importance of operating asphalt mixing plant quality criteria and rank correlation, Baltic Journal of Road and Bridge Engineering 6(1): 48-58. http://dx.doi.org/10.3846/bjrbe.2011.07

Sivilevičius, H. 2011b. Modelling the interaction of transport system elements, Transport 26(1): 20-34. http://dx.doi.org/10.3846/16484142.2011.560366

Sivilevičius, H.; Maskeliūnaitè, L. 2010. The criteria for identifying the quality of passengers' transportation by railway and their ranking using AHP method, Transport 25(4): 368-381. http://dx.doi.org/10.3846/transport.2010.46

Spathis, C.; Kosmidou, K.; Doumpos, M. 2002. Assessing profitability factors in the Greek banking system: a multi-criteria methodology, International Transactions in Operational Research 9: 517-530. http://dx.doi.org/10.1111/1475-3995.00371

Tamošaitienè, J.; Zavadskas, E. K.; Turskis, Z.; Vainiūnas, P. 2011. Multi-criteria complex for construction profitability analysis of construction projects, Ekonomika ir vadyba [Economics and Management] 16: 969-973. 
Tupenaite, L.; Zavadskas, E. K.; Kaklauskas, A.; Turskis, Z.; Seniut, M. 2010. Multiple criteria assessment of alternatives for built and human environment renovation, Journal of Civil Engineering and Management 16(2): 257-266. http://dx.doi.org/10.3846/jcem.2010.30

Weber, C. A. 1996. A data envelopment analysis approach to measuring vendor performance, Supply Chain Management 1(1): 28-39. http://dx.doi.org/10.1108/13598549610155242

Wilcox, J. W. 1984. The P/B-ROE valuation model, Financial Analysis Journal Jan-Feb: 58-66. http://dx.doi.org/10.2469/faj.v40.n1.58

Wu, C. R.; Lin, C. T.; Tsai, P. H. 2010. Evaluating business performance of wealth management banks, European Journal of Operational Research 207: 971-979. http://dx.doi.org/10.1016/j.eswa.2009.01.005

Yeh, Q. 1996. The application of data envelopment analysis in conjunction with financial ratios for bank performance evaluation, Journal of the Operational Research Society 47: 980-988.

Zavadskas, E. K.; Kaklauskas, A.; Turskis, Z.; Tamošaitiene, J. 2009a. Multi-attribute decision-making model by applying grey numbers, Informatica 20(2): 305-320.

Zavadskas, E. K.; Kaklauskas, A.; Vilutiene, T. 2009b. Multicriteria evaluation of apartments blocks maintenance contractors: Lithuanian case study, International Journal of Strategic Property Management 13(4): 319-338. http://dx.doi.org/10.3846/1648-715X.2009.13.319-338

Zavadskas, E. K.; Turskis, Z.; Tamosaitiene, J. 2008. Contractor selection of construction in a competitive environment, Journal of Business Economics and Management 9(3): 181-187.

http://dx.doi.org/10.3846/1611-1699.2008.9.181-187

Jelena STANKEVIČIENĖ. Assoc. Prof., PhD at the Department of Finance Engineering, Vilnius Gediminas Technical University (Lithuania), the Dean of the Faculty of Business Management. Research interests: assets and liability management, regulation of financial institution, financial management of value creation, value engineering.

Evelina MENCAITĖ. MSc in Business from Vilnius Gediminas Technical University (Lithuania), the Faculty of Business Management. Research interests: management of financial institutions, valuation models, fund rising. 